\title{
Assessment of composition and calcination parameters in Fischer-Tropsch synthesis over $\mathrm{Fe}-\mathrm{Mn}-\mathrm{Ce} / \gamma-\mathrm{Al}_{2} \mathrm{O}_{3}$ nanocatalyst
}

\author{
Reza Roknabadi ${ }^{1}$, Ali Akbar Mirzaei ${ }^{1, *}$, and Hossein Atashi ${ }^{2}$ \\ ${ }^{1}$ Department of Chemistry, Faculty of Sciences, University of Sistan and Baluchestan, 98164-161 Zahedan, Iran \\ ${ }^{2}$ Department of Chemical Engineering, University of Sistan and Baluchestan, 98164-161 Zahedan, Iran
}

Received: 24 September 2020 / Accepted: 13 November 2020

\begin{abstract}
The effects of nanocatalyst composition and calcination parameters on the performance of the $\mathrm{Fe}-\mathrm{Mn}-\mathrm{Ce}$ ternary nanocatalysts supported on alumina granules in a laboratory fixed bed microreactor have been evaluated. Nanocatalysts were synthesized by incipient wetness impregnation under vacuum method (simultaneous impregnation of metal species). The samples used for hydrogenation of carbon monoxide via Fischer-Tropsch synthesis. The optimum nanocatalyst composition for production of light olefins $\left(\mathrm{C}_{2}^{=}-\mathrm{C}_{4}^{=}\right)$ from synthesis gas is $75 \mathrm{wt} \% \mathrm{Fe}-20 \mathrm{wt} \% \mathrm{Mn}-5 \mathrm{wt} \% \mathrm{Ce}$. The calcination parameters (temperature, time and atmosphere) were investigated and their effects on the structure and performance of the nanocatalysts were determined. The maximum ratio of olefins/(methane + paraffin) and the best activity and selectivity belonged to the nanocatalyst which was calcined in static air at $500{ }^{\circ} \mathrm{C}$ for $7 \mathrm{~h}$. The nanocatalyst precursors and calcined samples (fresh and used) were characterized by XRD, $\mathrm{N}_{2}$ physisorption, FE-SEM, EDAX, MAP, TG, DSC, and $\mathrm{H}_{2}-\mathrm{TPR}$. The present study results confirm that the structural, morphological and physic-chemical properties of the nanocatalyst have been impressed with metal species and calcination parameters.
\end{abstract}

\section{Introduction}

Fischer-Tropsch Synthesis (FTS) as a favorite heterogeneous catalytic process for the chemical industry and research teams is the conversion of synthesis gas $\left(\mathrm{H}_{2}+\mathrm{CO}\right)$ into a mixture of hydrocarbons with the advantages of low content of toxic and carcinogenic pollutants including sulfur and aromatics [1-11]. Light olefins $\left(\mathrm{C}_{2}^{=}-\mathrm{C}_{4}^{=}\right)$as part of hydrocarbons, are extremely important because they are feedstocks for the synthesis of economically valuable products such as polymers, detergents and solvents $[12,13]$. Group VIII B transition metals, such as Fe, Co, Ni and Ru, are the most common FTS catalysts [14-16]. Two reasonable and successful FTS catalysts are $\mathrm{Fe}$ and $\mathrm{Co}$ [17-19]. Iron-based catalysts as affordable choice, are of interest in chemical industries also they are suitable for CO-rich synthesis gas due to their activity to water gas shift reaction [11, 20]. Furthermore, having benefits such as proper selectivity to the light olefins, high CO conversion, and compatibility to the operating conditions has distinguished iron-based catalysts from others [21-23]. In recent years, the Fe-Mn bimetallic catalyst systems have been noticed because of their high olefin selectivity and excellent stability [24-31]. The results

\footnotetext{
* Corresponding author: mirzaei.usb@gmail.com;

mirzaei@hamoon.usb.ac.ir
}

obtained by Maiti et al. [32] showed that in iron-manganese catalysts, if manganese content is low the interaction of the metals is significant and the formation of light olefins increases. The positive role of rare-earth metal oxides especially ceria on thermal stability, selectivity and activity of FT catalysts has been confirmed [33]. The studies of Barrault et al. $[34,35]$ revealed that addition of $\mathrm{CeO}_{2}$ as a promoter has been increased $\mathrm{CO}$ hydrogenation due to $\mathrm{C}-\mathrm{O}$ bond weakening. It is well known that the most popular supports for FT catalysts are silica, alumina and titania [36-39]. In present study, the catalytic performance of $\mathrm{Fe}-\mathrm{Mn}-\mathrm{Ce}$ ternary nanocatalyst supported on alumina granules (shaped support) for CO hydrogenation via FTS was evaluated for the first time. Calcination parameters influence on the morphology, specific surface area and texture of the catalyst and eventually influence on its performance. Rankin and Bartholomew [40, 41] found that calcination temperature increasing of potassium-promoted iron/silica catalyst decreases reduction degree of the catalyst. As well as reduces catalyst adsorption abilities for $\mathrm{CO}$ and $\mathrm{H}_{2}$. In our previous studies [24, 42-46], we indicated the importance of calcination parameters also, the obtained results have demonstrated that the change in the calcination parameters leads to more thermodynamically stable phase changing. The main goal of this study is to assessment the influence of nanocatalyst composition and calcination parameters on the activity and selectivity 
of iron-manganese-cerium mixed oxide nanocatalyst prepared by incipient wetness impregnation under vacuum method in a fixed-bed reactor for light olefins production via FT synthesis. The structural investigations of precursors and calcined samples (before and after FTS) were carried out using different techniques including X-Ray diffraction, BET, FE-SEM, EDAX, MAP, TG, DSC, and $\mathrm{H}_{2}-\mathrm{TPR}$.

\section{Experimental}

\subsection{Catalyst preparation and testing}

The $\mathrm{Fe}-\mathrm{Mn}-\mathrm{Ce}$ ternary catalysts supported on $\gamma-\mathrm{Al}_{2} \mathrm{O}_{3}$ granules were synthesized by the following incipient wetness impregnation under vacuum method. Initially, the shaped supports were heated at $500{ }^{\circ} \mathrm{C}$ for $6 \mathrm{~h}$ with $1{ }^{\circ} \mathrm{C} \min ^{-1}$ heating rate. Subsequently the certain amount of $\mathrm{Fe}\left(\mathrm{NO}_{3}\right)_{3} .9 \mathrm{H}_{2} \mathrm{O}$ (98\%, Merck, Germany), Mn $\left(\mathrm{NO}_{3}\right)_{2} .4 \mathrm{H}_{2} \mathrm{O}$ (98.5\%, Merck, Germany), $\mathrm{Ce}\left(\mathrm{NO}_{3}\right)_{3} .6 \mathrm{H}_{2} \mathrm{O}$ salts were mixed together in double distillated water completely. The calcined $\gamma-\mathrm{Al}_{2} \mathrm{O}_{3}$ support added into twonecked flask attached to vacuum pump. When the vacuum reaches 200 mbar, we inject iron-manganese-cerium metal nitrate solution (simultaneous impregnation of metal species). Obtained sample was rotated in rotary evaporator that device was set up in $80^{\circ} \mathrm{C}$ for $1 \mathrm{~h}$ under nitrogen atmosphere (Nitrogen dynamic). The aged granules were filtered and dried for $8 \mathrm{~h}$ at $120{ }^{\circ} \mathrm{C}$ in electric oven (Air dynamic). The precursor calcination is performed in electric furnace in static air at $500{ }^{\circ} \mathrm{C}$ for $6 \mathrm{~h}$. This provides a fresh calcined catalyst that is ready to be tested in the laboratory fixed bed micro reactor. The weight ratio of metals/support in all catalysts was 10/90. The final formed catalyst was kept in desiccator.

All experiments were conducted in a laboratory fixed bed tubular micro reactor. In each test, $1.0 \mathrm{~g}$ calcined sample was held in middle of the reactor. It was activated using pure hydrogen with a flow rate of $40 \mathrm{~mL} / \mathrm{min}$ at $400{ }^{\circ} \mathrm{C}$ for $4 \mathrm{~h}$. The FT reaction was performed under the same reaction conditions of $T=300{ }^{\circ} \mathrm{C}, P=1.2$ bar, $\mathrm{H}_{2} / \mathrm{CO}=2: 1$ and GHSV $=2400 \mathrm{~h}^{-1}$. After $15 \mathrm{~h}$, the system reaches steady state. Finally, the reactant and product analysis was carried out using an online gas chromatograph (UNICAM PROGC ${ }^{+}$, TERMO ONIX, USA).

The catalytic activity is shown in the form of $\mathrm{CO}$ conversion (\%) in the different reaction conditions. The $\mathrm{CO}$ conversion (\%), $\mathrm{CO}_{2}$ selectivity (\%) and hydrocarbon selectivity $(\%)$ were calculated through following equations:

CO conversion (\% moles)

$X_{\mathrm{CO}}(\%)=\frac{(\text { Inlet moles of CO })-(\text { Outlet moles of CO })}{(\text { Inlet moles of CO })} \times 100$.

$$
\mathrm{CO}_{2} \text { selectivity (\% moles) }
$$

$X_{\mathrm{CO}_{2}}(\%)=\frac{\left(\text { Outlet moles of } \mathrm{CO}_{2}\right)}{(\text { Inlet moles of } \mathrm{CO})-(\text { Outlet moles of } \mathrm{CO})} \times 100$

$$
\begin{aligned}
& \text { C }_{n} \text { selectivity (\% C- atoms) } \\
& \qquad S_{\mathrm{C}_{n}}(\%)=\frac{n_{\mathrm{i}} M_{\mathrm{i}}}{\sum n_{\mathrm{i}} M_{\mathrm{i}}} \times 100,
\end{aligned}
$$

where $n_{\mathrm{i}}$ and $M_{\mathrm{i}}$ are the carbon atoms numbers in the species $i$ and the percentage of species i, respectively.

\subsection{Catalyst characterization}

The X-Ray Diffraction (XRD) patterns of the entire precursor, fresh and used calcined samples were recorded on D8 Advance diffractometer (Bruker AXS, Germany). Scans were taken with a $2 \theta$ step size of $0.02^{\circ}$ and a counting time of 1.0 s using a $\mathrm{Cu} \mathrm{K} \alpha$ radiation source (40 KV and $30 \mathrm{~mA}$ ) in the $2 \theta$ range of $10^{\circ}-80^{\circ}$.

BET specific surface area, pore volume and average pore size of the catalysts includes precursor, fresh and used calcined samples were measured by $\mathrm{N}_{2}$ physisorption using a Specific Surface Area and Porosity Analyzer Quanta chrome Nova 2000 automated system (USA). During analysis, all samples were evacuated at $-196^{\circ} \mathrm{C}$ for $66 \mathrm{~min}$.

Field Emission Scanning Electron Microscopy (FE-SEM), Energy Dispersive X-ray (EDAX) spectrometer and Metal Mapping (MAP) analysis were performed by a FE-SEM model MIRA3 TESCAN-XMU (Czech-Republic) instrument. The morphology of the catalysts and their precursor is visible through field emission scanning electron microscope images. The maximum resolution of instrument was $1.2 \mathrm{~nm}$ and all samples were sputtered with a thin film of gold.

The weight loss of precursor was evaluated by thermal gravimetric analysis and differential scanning calorimetric (TG/DSC) by a simultaneous thermal analyzer (STA 503, B̈̈HR-Thermoanalyse GmbH, Germany) instrument. The initial weight of sample was between 10 and $20 \mathrm{mg}$.

The $\mathrm{H}_{2}$-Temperature Programmed Reduction $\left(\mathrm{H}_{2}-\mathrm{TPR}\right)$ experiment was carried out to study the reducibility of the catalyst. The $\mathrm{H}_{2}-\mathrm{TPR}$ was performed by a NanoSORD NS91 (Iran) apparatus on $30 \mathrm{mg}$ of optimal catalyst placed in a U-shaped quartz reactor. The sample was heated from room temperature to $950{ }^{\circ} \mathrm{C}$ at a heating rate of $10{ }^{\circ} \mathrm{C} / \mathrm{min}$.

\section{Results and discussion}

\subsection{Assessment of the catalyst composition}

Nowadays, direct conversion of synthesis gas (syngas) to mix of hydrocarbons especially light olefins via FTS is an attractive technology all around the world. The light olefins including $\mathrm{C}_{2} \mathrm{H}_{4}, \mathrm{C}_{3} \mathrm{H}_{6}$ and $\mathrm{C}_{4} \mathrm{H}_{8}$ are the most important monomers as raw material in the polymer industry. The effects of weight ratio of metal component and calcination parameters on the $\mathrm{CO}$ conversion and products selectivity were evaluated. At all stages of the present research, the optimum catalyst was identified with respect to maximize of $\mathrm{CO}$ conversion (catalyst activity) and $\mathrm{C}_{2}^{=}-\mathrm{C}_{4}^{=}$olefins production (desired products), inhibition of $\mathrm{C}_{2}^{0}-\mathrm{C}_{4}^{0}$ paraffins and $\mathrm{CH}_{4}$ formation (undesired products). But the most 
Table 1. Catalytic performance of $\mathrm{Fe}-\mathrm{Mn}-\mathrm{Ce}$ nanocatalysts with different metal weight ratios.

\begin{tabular}{lccccccc}
\hline Catalyst & $\mathrm{CO}$ conversion (\%) & $\mathrm{CO}_{2}$ selectivity $(\%)$ & \multicolumn{3}{c}{ Hydrocarbon selectivity $(\mathrm{C} \%)$} & $\mathrm{O} /(\mathrm{M}+\mathrm{P})$ ratio \\
\cline { 3 - 6 } & & & $\mathrm{CH}_{4}$ & $\mathrm{C}_{2}^{=}-\mathrm{C}_{4}^{=}$ & $\mathrm{C}_{2}^{0}-\mathrm{C}_{4}^{0}$ & $\mathrm{C}_{5}{ }^{+}$ & \\
\hline 85Fe10Mn05Ce & 24.87 & 12.6 & 19.33 & 5.58 & 71.36 & 3.73 & 0.06 \\
80Fe10Mn10Ce & 27.68 & 10.24 & 20.7 & 6.17 & 72 & 1.13 & 0.07 \\
75Fe10Mn15Ce & 29.86 & 13.63 & 27.53 & 9.81 & 60.37 & 2.29 & 0.11 \\
$\mathbf{7 5 F e 2 0 M n 0 5 C e}$ & $\mathbf{2 5 . 6 1}$ & $\mathbf{1 2 . 3}$ & $\mathbf{2 5 . 6 3}$ & $\mathbf{1 7 . 7 6}$ & $\mathbf{5 2 . 5}$ & $\mathbf{4 . 1 1}$ & $\mathbf{0 . 2 3}$ \\
70Fe20Mn10Ce & 26.94 & 10.99 & 20.13 & 8.73 & 68.94 & 2.61 & 0.1 \\
65Fe20Mn15Ce & 27.24 & 8.19 & 19.51 & 3.94 & 73 & 3.56 & 0.04 \\
65Fe30Mn05Ce & 23.66 & 7.72 & 18.76 & 9.11 & 68.27 & 3.86 & 0.1 \\
60Fe30Mn10Ce & 27.68 & 10.24 & 20.98 & 6.17 & 72 & 0.85 & 0.07 \\
55Fe30Mn15Ce & 23.73 & 8.55 & 22.48 & 11.34 & 64.98 & 1.21 & 0.13
\end{tabular}

Note. The bold values show the optimal condition.

important component for choosing the optimal catalyst was the maximum amount for the ratio of olefins to the summation of methane and paraffins which in this case is shown $(\mathrm{O} /(\mathrm{M}+\mathrm{P}))$. A set of $\mathrm{Fe}-\mathrm{Mn}-\mathrm{Ce}$ ternary nanocatalysts was synthesized by the incipient wetness impregnation under vacuum procedure. In the first step, to determine the optimum weight percentage of metal species, manganese and cerium values in the order of 10-30 and 5-15 were changed. The calcination of precursors are performed in electric furnace in static air at $500{ }^{\circ} \mathrm{C}$ for $6 \mathrm{~h}$. The calcined samples were tested in the laboratory fixed bed tubular micro reactor under same operating conditions of $T=300{ }^{\circ} \mathrm{C}, \mathrm{H}_{2} / \mathrm{CO}=2 / 1, P=1.2$ bar, and Gas Hourly Space Velocity (GHSV) $=2400 \mathrm{~h}^{-1}$ for FTS. With reaching to steady state after $15 \mathrm{~h}$, the activity and selectivity of iron-manganese - cerium ternary nanocatalysts were evaluated and have illustrated in Table 1.

Although the $\mathrm{CO}$ conversion values of all samples are similar, but the catalyst containing $75 \mathrm{wt} \% \mathrm{Fe}-20 \mathrm{wt} \%$ Mn-5 wt\%Ce has the maximum selectivity to $\mathrm{C}_{2}^{=}-\mathrm{C}_{4}^{=}$ olefins. Therefore, this catalyst was selected as the optimum catalyst due to the most ratio of $(\mathrm{O} /(\mathrm{M}+\mathrm{P}))$. The high selectivity toward light olefins is due to reasonable and sufficient content of iron and manganese in the optimum catalyst $[12,47]$.

Characterization of fresh calcined samples with different weight percentages was performed by X-ray Diffraction and the obtained patterns are demonstrated in Figure 1. The identified phases were $\mathrm{Fe}_{2} \mathrm{O}_{3}$ (hexagonal), $\mathrm{Fe}_{3} \mathrm{O}_{4}$ (cubic), $\mathrm{FeO}$ (cubic), $\mathrm{Mn}_{2} \mathrm{O}_{3}$ (orthorhombic), $\mathrm{Mn}_{3} \mathrm{O}_{4}$ (tetragonal), $\mathrm{CeO}_{2}$ (cubic) and $\mathrm{Al}_{2} \mathrm{O}_{3}$ (cubic). Also, characterization of the calcined $\mathrm{Fe}-\mathrm{Mn}-\mathrm{Ce} / \mathrm{Al}_{2} \mathrm{O}_{3}$ nanocatalysts with different weight percentages was performed by BET measurement and the results are reported in Table 2.

As it shown, the catalyst containing $75 \mathrm{wt} \% \mathrm{Fe}-20 \mathrm{wt} \%$ Mn-5 wt\%Ce has the highest specific surface area, thus the higher specific surface area of the catalyst has led to an increase in its catalytic activity.

\subsection{Assessment of calcination parameters}

After removing the solvent and drying the granules, more heat is required to the resulting precursors become catalytically useful for reactor testing, called calcination. Calcination parameters (temperature, time and atmosphere) influence on texture, specific surface area and morphology of the catalyst and eventually influence on performance of the catalyst. In present work, calcination parameters and their influences on the structure and performance of $\mathrm{Fe}-\mathrm{Mn}-\mathrm{Ce}$ ternary nanocatalysts supported on $\gamma-\mathrm{Al}_{2} \mathrm{O}_{3}$ were investigated.

\subsection{Calcination temperature}

In the second step, in order to evaluate the influence of calcination temperature on the catalytic performance of the $\mathrm{Fe}-\mathrm{Mn}-\mathrm{Ce}$ ternary nanocatalysts supported on $\gamma-\mathrm{Al}_{2} \mathrm{O}_{3}$ granules, a series of mixed iron manganese cerium oxide catalysts with the optimum weight ratios $(75 \% \mathrm{Fe}-20 \%$ $\mathrm{Mn}-5 \% \mathrm{Ce})$ were prepared with a range of calcination temperature between 400 and $700{ }^{\circ} \mathrm{C}$ for $6 \mathrm{~h}$. The catalytic performance of all nanocatalysts for the FTS was investigated under the same reactor conditions $\mathrm{H}_{2} / \mathrm{CO}=2 / 1$, GHSV $=2400 \mathrm{~h}^{-1}, P=1.2$ bar at $300{ }^{\circ} \mathrm{C}$. The results of catalytic performance of $\mathrm{Fe}-\mathrm{Mn}-\mathrm{Ce}$ nanocatalysts at calcination temperatures from 400 to $700{ }^{\circ} \mathrm{C}$ are shown in Table 3.

Compared to other catalysts, the precursor calcined at $500{ }^{\circ} \mathrm{C}$ has authenticated maximum selectivity to the light olefins. Therefore, $500{ }^{\circ} \mathrm{C}$ was elected as the optimum calcination temperature because of the most ratio of $(\mathrm{O} /(\mathrm{M}+\mathrm{P}))$. The XRD patterns of catalysts calcined at different temperatures are illustrated in Figure 2. The phases identified were $\mathrm{Fe}_{2} \mathrm{O}_{3}$ (hexagonal), $\mathrm{Fe}_{3} \mathrm{O}_{4}$ (cubic), $\mathrm{FeO}$ (cubic), $\mathrm{Mn}_{2} \mathrm{O}_{3}$ (orthorhombic), $\mathrm{Mn}_{3} \mathrm{O}_{4}$ (tetragonal), $\mathrm{CeO}_{2}$ (cubic) and $\mathrm{Al}_{2} \mathrm{O}_{3}$ (cubic).

Also, BET results of the calcined samples at temperatures from 400 to $700{ }^{\circ} \mathrm{C}$ are offered in Table 4 . It is obvious that the catalyst specific surface area at calcination temperature of $500{ }^{\circ} \mathrm{C}$ is higher than other temperatures. Considering the similarity of XRD spectra pattern of catalyst calcination at different temperatures and also of the same phases thus, the higher catalytic activity of the calcined catalyst at $500{ }^{\circ} \mathrm{C}$ can be attributed to the higher specific surface area and the increase of its surface active sites. 


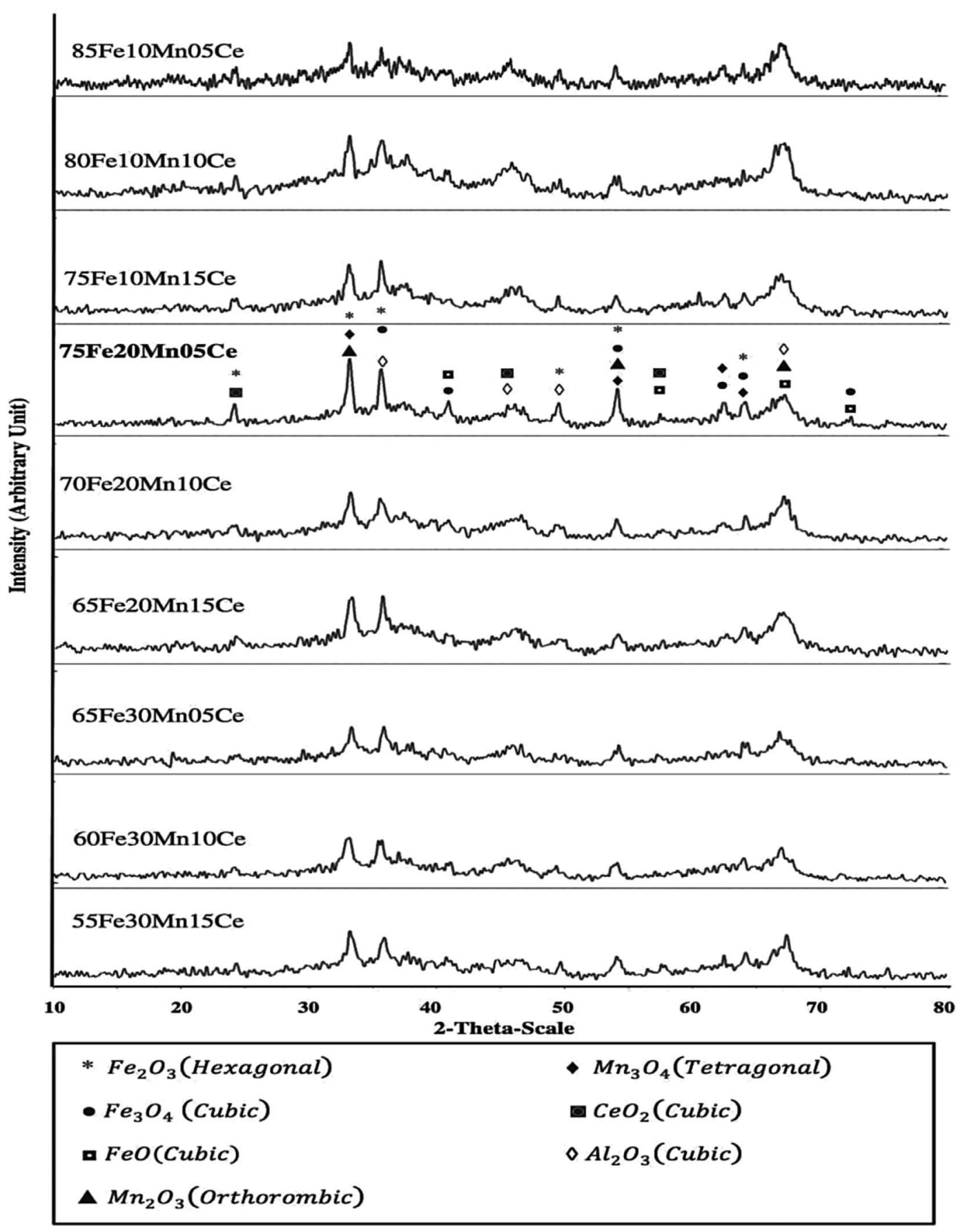

Fig. 1. The XRD patterns for calcined $\mathrm{Fe}-\mathrm{Mn}-\mathrm{Ce} / \mathrm{Al}_{2} \mathrm{O}_{3}$ nanocatalysts with different wt\%.

\subsection{Calcination time}

In the third step, it has been evaluated the influence of calcination time on the $\mathrm{CO}$ hydrogenation for the $\mathrm{Fe}-\mathrm{Mn}-\mathrm{Ce}$ ternary nanocatalysts supported on $\gamma-\mathrm{Al}_{2} \mathrm{O}_{3}$ granules. For this purpose, a series of mixed iron manganese cerium catalysts were calcined at $500{ }^{\circ} \mathrm{C}$ for different times in the range of $4-8 \mathrm{~h}$. The FTS reaction tests of all calcined samples were evaluated under following process conditions:
$\mathrm{H}_{2} / \mathrm{CO}=2 / 1, \mathrm{GHSV}=2400 \mathrm{~h}^{-1}, P=1.2$ bar at $300{ }^{\circ} \mathrm{C}$ and the obtained results are reported in Table 5 .

As it is clear, although the $\mathrm{CO}$ conversion in calcined sample at $500{ }^{\circ} \mathrm{C}$ for $7 \mathrm{~h}$ is not significantly different from other nanocatalysts, its selectivity toward light olefins is greater than other nanocatalysts. Therefore, the nanocatalyst calcined for $7 \mathrm{~h}$ was elected as the optimum nanocatalyst for the following reasons: the minimum production of methane, the maximum production of the light olefins 
Table 2. BET analysis of the $\mathrm{Fe}-\mathrm{Mn}-\mathrm{Ce} / \mathrm{Al}_{2} \mathrm{O}_{3}$ nanocatalysts with different wt\%.

\begin{tabular}{lccc}
\hline \multicolumn{1}{c}{ Catalyst } & \multicolumn{3}{c}{ Specific surface area $\left(\mathrm{m}^{2} / \mathrm{g}\right)$} \\
\hline 85Fe10Mn05Ce & Precursor & Fresh calcined (before test) & Used calcined (after test) \\
80Fe10Mn10Ce & 134.2 & 155.4 & 147.9 \\
$75 \mathrm{Fe} 10 \mathrm{Mn} 15 \mathrm{Ce}$ & 144.6 & 165.3 & 153.2 \\
$\mathbf{7 5 F e 2 0 M n 0 5 C e}$ & 125.9 & 148.7 & 136.4 \\
$70 \mathrm{Fe} 20 \mathrm{Mn} 10 \mathrm{Ce}$ & $\mathbf{1 5 7 . 3}$ & $\mathbf{1 9 8 . 7}$ & $\mathbf{1 6 4 . 2}$ \\
65Fe20Mn15Ce & 146.4 & 172.1 & 156.9 \\
65Fe30Mn05Ce & 120.7 & 139.8 & 128.3 \\
60Fe30Mn10Ce & 136.7 & 173.5 & 162.8 \\
$55 \mathrm{Fe} 30 \mathrm{Mn} 15 \mathrm{Ce}$ & 138.1 & 164.2 & 149.4 \\
85Fe10Mn05Ce & 129.8 & 149.6 & 135.7 \\
\hline
\end{tabular}

Note. The bold values show the optimal condition.

Table 3. Catalytic performance of $\mathrm{Fe}-\mathrm{Mn}-\mathrm{Ce}$ nanocatalysts at different calcination temperatures.

\begin{tabular}{lccccccc}
\hline $\begin{array}{l}\text { Calcination } \\
\text { temperature }\left({ }^{\circ} \mathrm{C}\right)\end{array}$ & $\begin{array}{c}\mathrm{CO} \text { Conversion } \\
(\%)\end{array}$ & $\begin{array}{c}\mathrm{CO}_{2} \text { Selectivity } \\
(\%)\end{array}$ & \multicolumn{3}{c}{ Hydrocarbon selectivity $(\mathrm{C} \%)$} & \multirow{\mathrm{O}}{*}{$/(\mathrm{M}+\mathrm{P})$} \\
\cline { 4 - 6 } & & $\mathrm{CH}_{4}$ & $\mathrm{C}_{2}^{=}-\mathrm{C}_{4}^{=}$ & $\mathrm{C}_{2}^{0}-\mathrm{C}_{4}^{0}$ & $\mathrm{C}_{5}{ }^{+}$ & & ratio \\
\hline 400 & 24.07 & 11.32 & 19.81 & 6.93 & 70.39 & 2.86 & 0.08 \\
450 & 25.08 & $\mathbf{1 2 . 3 0}$ & $\mathbf{2 5 . 6 3}$ & $\mathbf{1 7 . 7 6}$ & $\mathbf{5 2 . 5 0}$ & $\mathbf{4 . 1 1}$ & $\mathbf{0 . 2 3}$ \\
$\mathbf{5 0 0}$ & $\mathbf{2 5 . 6 1}$ & 9.68 & 21.97 & 12.69 & 62.00 & 3.34 & 0.15 \\
550 & 23.33 & 8.32 & 16.71 & 9.64 & 70.73 & 2.92 & 0.11 \\
600 & 24.24 & 8.16 & 20.82 & 12.16 & 65.49 & 1.53 & 0.14 \\
650 & 23.96 & 8.32 & 20.33 & 5.44 & 70.75 & 3.47 & 0.06 \\
700 & 25.55 & & &
\end{tabular}

Note. The bold values show the optimal condition.

and eventually the most ratio of $(\mathrm{O} /(\mathrm{M}+\mathrm{P}))$. The XRD patterns of the $\mathrm{Fe}-\mathrm{Mn}-\mathrm{Ce} / \mathrm{Al}_{2} \mathrm{O}_{3}$ catalysts, which range from 4 to $8 \mathrm{~h}$ calcination time, are shown in Figure 3.

The results are shown that all of the calcined samples are comprised of same crystalline phases $\mathrm{Fe}_{2} \mathrm{O}_{3}$ (hexagonal), $\mathrm{Fe}_{3} \mathrm{O}_{4}$ (cubic), $\mathrm{FeO}$ (cubic), $\mathrm{Mn}_{2} \mathrm{O}_{3}$ (orthorhombic), $\mathrm{Mn}_{3} \mathrm{O}_{4}$ (tetragonal), $\mathrm{CeO}_{2}$ (cubic) and $\mathrm{Al}_{2} \mathrm{O}_{3}$ (cubic). Furthermore, BET measurements of calcined catalysts at different times were carried out and the related results are offered in Table 6 .

It is quite clear that the catalyst specific surface area at calcination time of $7 \mathrm{~h}$ is higher than other times. Therefore, the higher catalytic activity of the calcined catalyst at $7 \mathrm{~h}$ can be attributed to higher specific surface area, smaller particles, and increased surface active sites.

\subsection{Calcination atmosphere}

At the last step, the influence of two different calcination atmospheres on the hydrogenation of $\mathrm{CO}$ was evaluated. The Fe-Mn-Ce precursors were calcined at $500{ }^{\circ} \mathrm{C}$ for $7 \mathrm{~h}$ under two different environments air and nitrogen. These samples were tested in the laboratory micro reactor under the same reaction conditions $\mathrm{H}_{2} / \mathrm{CO}=2 / 1$, GHSV $=$ $2400 \mathrm{~h}^{-1}, P=1.2$ bar at $300^{\circ} \mathrm{C}$ for FTS and the obtained results are reported in Table 7 .
The results showed that, the sample calcined under air has identified the best selectivity to desired products $\mathrm{C}_{2}^{=}-\mathrm{C}_{4}^{=}$light olefins. Consequently, air was elected as the optimum calcination atmosphere of the $\mathrm{Fe}-\mathrm{Mn}-\mathrm{Ce} /$ $\mathrm{Al}_{2} \mathrm{O}_{3}$ nanocatalyst due to the maximum $(\mathrm{O} /(\mathrm{M}+\mathrm{P}))$ ratio. The results of this step are similar to some of the previous studies in which catalysts with active phases such as iron, cobalt, or nickel were calcined in air, they had better activity and selectivity than calcined samples in neutral atmosphere $[46,48]$. Structural analysis of the nanocatalysts calcined at $500{ }^{\circ} \mathrm{C}$ for $7 \mathrm{~h}$ under two different atmospheres was carried out by X-ray diffraction, the obtained patterns are presented in Figure 4.

It can be seen that, the catalyst calcined under air atmosphere is comprised of oxide phases including: $\mathrm{Fe}_{2} \mathrm{O}_{3}$ (hexagonal), $\mathrm{Fe}_{3} \mathrm{O}_{4}$ (cubic), $\mathrm{FeO}$ (cubic), $\mathrm{Mn}_{2} \mathrm{O}_{3}$ (orthorhombic), $\mathrm{Mn}_{3} \mathrm{O}_{4}$ (tetragonal), $\mathrm{CeO}_{2}$ (cubic) and $\mathrm{Al}_{2} \mathrm{O}_{3}$ (cubic) but, the calcined sample under nitrogen atmosphere is comprised of oxide and nitride phases including: $\mathrm{Fe}_{2} \mathrm{O}_{3}$ (cubic), $\mathrm{CeN}$ (cubic), $\mathrm{Fe}_{2} \mathrm{~N}$ (orthorhombic) and $\mathrm{Al}_{2} \mathrm{O}_{3}$ (hexagonal). The results of $\mathrm{X}$-ray diffraction show that the change in the calcination atmosphere has caused changes in the formed phases of the $\mathrm{Fe}-\mathrm{Mn}-\mathrm{Ce}$ ternary nanocatalyst. Thus the difference in performance of these two catalysts is due to the formed phases. For as much as the sample calcined under air has verified the best 


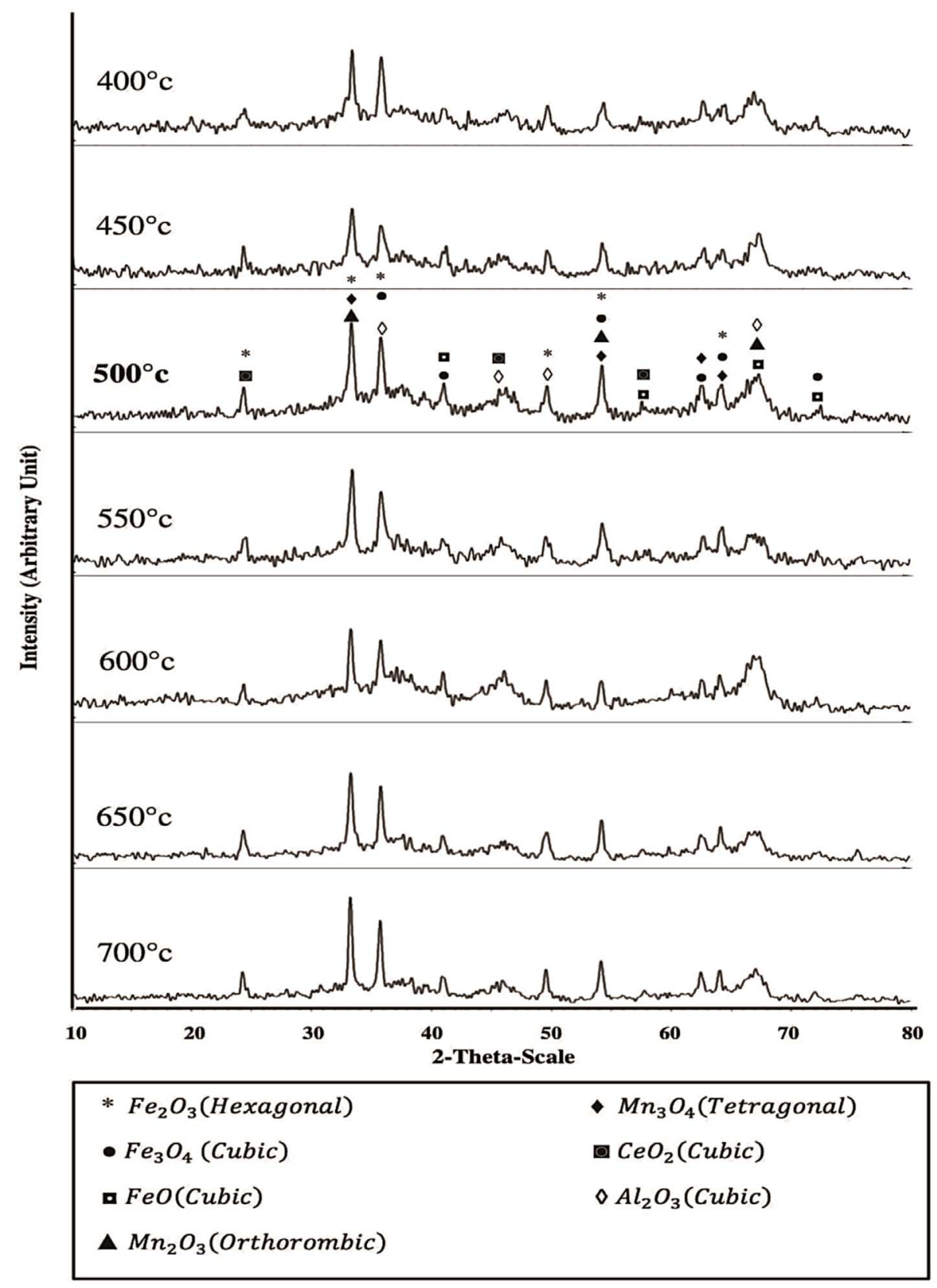

Fig. 2. The XRD patterns of $\mathrm{Fe}-\mathrm{Mn}-\mathrm{Ce} / \mathrm{Al}_{2} \mathrm{O}_{3}$ catalysts calcined at different temperatures.

Table 4. BET analysis of the Fe-Mn-Ce/ $\mathrm{Al}_{2} \mathrm{O}_{3}$ nanocatalysts calcined at different temperatures.

\begin{tabular}{lccc}
\hline & \multicolumn{2}{c}{ Specific surface area $\left(\mathrm{m}^{2} / \mathrm{g}\right)$} & $\begin{array}{c}\text { Used calcined } \\
\text { (after test) }\end{array}$ \\
\hline $\begin{array}{l}\text { Calcination } \\
\text { temperature }\left({ }^{\circ} \mathrm{C}\right)\end{array}$ & Precursor & $\begin{array}{c}\text { Fresh calcined } \\
\text { (before test) }\end{array}$ & 154.8 \\
\hline 400 & 157.3 & 172.6 & 159.1 \\
450 & 157.3 & 181.4 & $\mathbf{1 6 4 . 2}$ \\
$\mathbf{5 0 0}$ & $\mathbf{1 5 7 . 3}$ & $\mathbf{1 9 8 . 7}$ & 155.7 \\
550 & 157.3 & 176.5 & 153.2 \\
600 & 157.3 & 173.8 & 147.6 \\
650 & 157.3 & 168.6 & 136.3 \\
700 & 157.3 & 166.2 & \\
\hline
\end{tabular}

Note. The bold values show the optimal condition. 
Table 5. Catalytic performance of Fe-Mn-Ce nanocatalysts at different calcination times.

\begin{tabular}{|c|c|c|c|c|c|c|c|}
\hline \multirow{2}{*}{$\begin{array}{l}\text { Calcination } \\
\text { time (h) }\end{array}$} & \multirow{2}{*}{$\begin{array}{c}\text { CO Conversion } \\
(\%)\end{array}$} & \multirow{2}{*}{$\begin{array}{c}\mathrm{CO}_{2} \text { selectivity } \\
(\%)\end{array}$} & \multicolumn{4}{|c|}{ Hydrocarbon selectivity (C\%) } & \multirow{2}{*}{$\begin{array}{c}\mathrm{O} /(\mathrm{M}+\mathrm{P}) \\
\text { ratio }\end{array}$} \\
\hline & & & $\mathrm{CH}_{4}$ & $\mathrm{C}_{2}^{=}-\mathrm{C}_{4}^{=}$ & $\mathrm{C}_{2}^{0}-\mathrm{C}_{4}^{0}$ & $\mathrm{C}_{5}^{+}$ & \\
\hline 4 & 24.56 & 7.61 & 22.19 & 5.11 & 69.84 & 2.86 & 0.06 \\
\hline 5 & 23.27 & 9.96 & 22.9 & 8.6 & 65.42 & 3.08 & 0.1 \\
\hline 6 & 25.61 & 12.3 & 25.63 & 17.76 & 52.5 & 4.11 & 0.23 \\
\hline 7 & 24.04 & 5.91 & 13.87 & 24.06 & 58.73 & 3.34 & 0.33 \\
\hline 8 & 27.18 & 12.94 & 33.54 & 14.34 & 49.2 & 2.92 & 0.17 \\
\hline
\end{tabular}

Note. The bold values show the optimal condition.

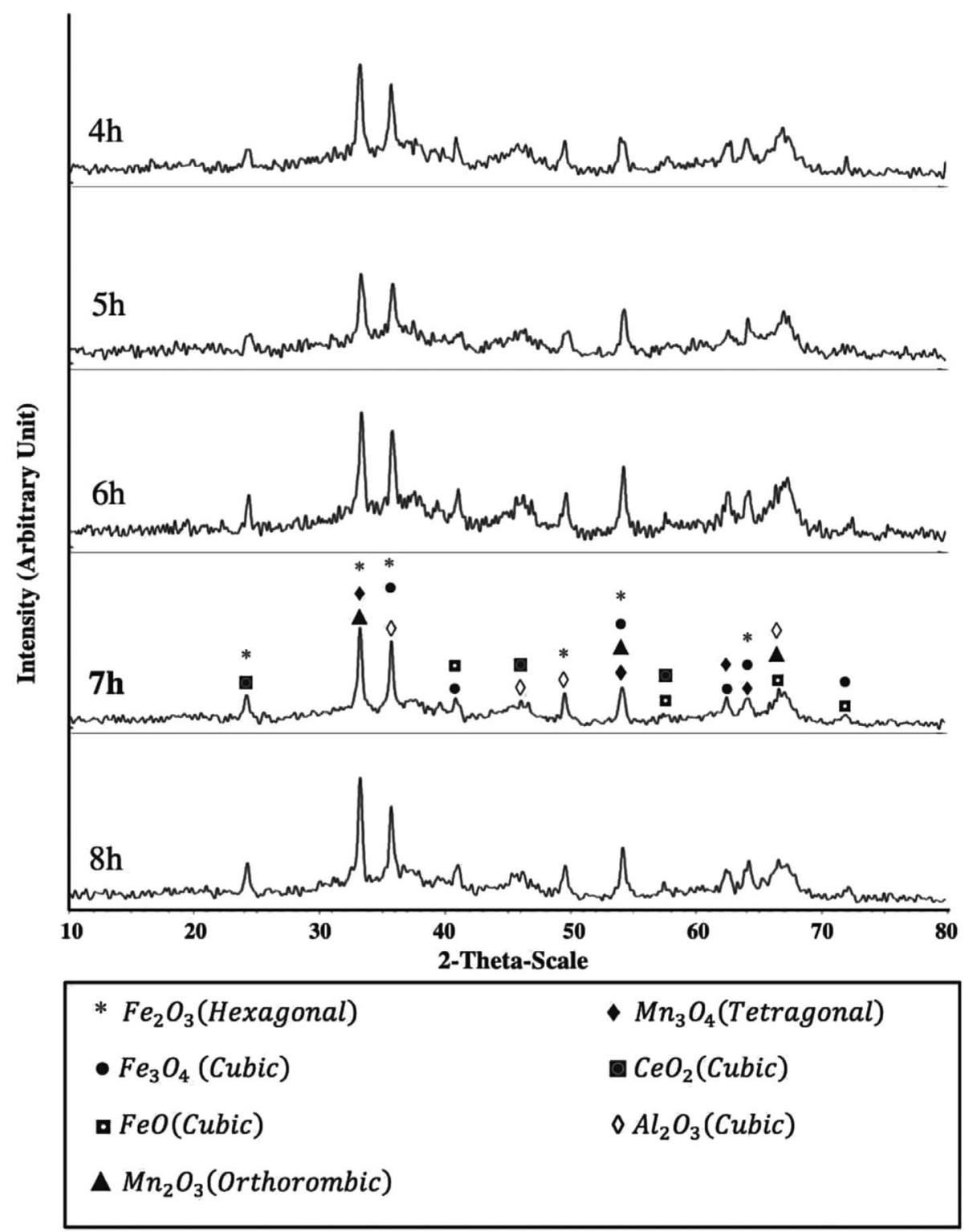

Fig. 3. The XRD patterns of $\mathrm{Fe}-\mathrm{Mn}-\mathrm{Ce} / \mathrm{Al}_{2} \mathrm{O}_{3}$ catalysts calcined at different times. 
Table 6. BET analysis of the Fe-Mn-Ce/ $\mathrm{Al}_{2} \mathrm{O}_{3}$ nanocatalysts calcined at different times.

\begin{tabular}{lccc}
\hline \multicolumn{3}{c}{ Specific surface area $\left(\mathrm{m}^{2} / \mathrm{g}\right)$} & \\
\hline Used calcined (after test) & Fresh calcined (before test) & Precursor & Calcination time $(\mathrm{h})$ \\
\hline 4 & 157.3 & 163.7 & 141.6 \\
5 & 157.3 & 175.9 & 156.3 \\
6 & 157.3 & 198.7 & 164.2 \\
$\mathbf{7}$ & $\mathbf{1 5 7 . 3}$ & $\mathbf{2 1 2 . 2}$ & $\mathbf{1 9 6 . 8}$ \\
8 & 157.3 & 184.1 & 172.9 \\
\hline
\end{tabular}

Note. The bold values show the optimal condition.

Table 7. Catalytic performance of Fe-Mn-Ce nanocatalysts at different calcination atmospheres.

\begin{tabular}{|c|c|c|c|c|c|c|c|}
\hline \multirow{2}{*}{$\begin{array}{l}\text { Calcination } \\
\text { atmosphere }\end{array}$} & \multirow{2}{*}{$\begin{array}{c}\text { CO Conversion } \\
(\%)\end{array}$} & \multirow{2}{*}{$\begin{array}{c}\mathrm{CO}_{2} \text { Selectivity } \\
(\%)\end{array}$} & \multicolumn{4}{|c|}{ Hydrocarbon selectivity (C \%) } & \multirow{2}{*}{$\begin{array}{c}\mathrm{O} /(\mathrm{M}+\mathrm{P}) \\
\text { ratio }\end{array}$} \\
\hline & & & $\mathrm{CH}_{4}$ & $\mathrm{C}_{2}^{=}-\mathrm{C}_{4}^{=}$ & $\mathrm{C}_{2}^{0}-\mathrm{C}_{4}^{0}$ & $\mathrm{C}_{5}{ }^{+}$ & \\
\hline 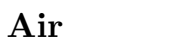 & 24.04 & 5.91 & 13.87 & 24.06 & 58.73 & 3.34 & 0.33 \\
\hline Nitrogen & 25.69 & 15.66 & 33.55 & 8.22 & 56.40 & 1.83 & 0.09 \\
\hline
\end{tabular}

Note. The bold values show the optimal condition.

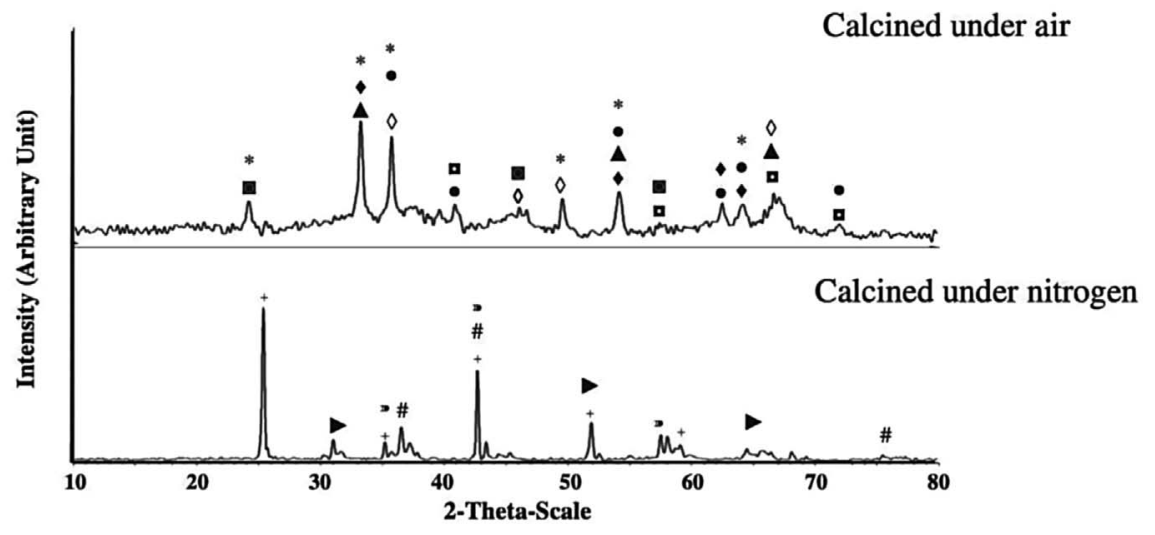

\begin{tabular}{|c|c|c|}
\hline Calcined under air phases: & $\begin{array}{l}\mathrm{Fe}_{2} \mathrm{O}_{3} \text { (Hexagonal) } \\
\text { - } \mathrm{Fe}_{3} \mathrm{O}_{4}(\text { Cubic }) \\
\text { - } \mathrm{FeO}(\text { Cubic }) \\
\mathrm{\triangle} \mathrm{Mn}_{2} \mathrm{O}_{3} \text { (Orthorombic) }\end{array}$ & 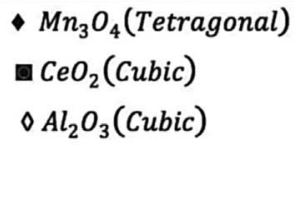 \\
\hline Calcined under nitrogen phases: & $\begin{array}{l}\mathrm{Fe}_{2} \mathrm{O}_{3}(\mathrm{Cubic}) \\
-\mathrm{CeN}(\text { Cubic }) \\
\# \mathrm{Fe}_{2} \mathrm{~N}(\text { Orthorhombic }) \\
+\mathrm{Al}_{2} \mathrm{O}_{3} \text { (Hexagonal) }\end{array}$ & \\
\hline
\end{tabular}

Fig. 4. The $\mathrm{XRD}$ patterns of $\mathrm{Fe}-\mathrm{Mn}-\mathrm{Ce} / \mathrm{Al}_{2} \mathrm{O}_{3}$ catalysts calcined at different atmospheres.

Table 8. BET analysis of the Fe-Mn-Ce/ $\mathrm{Al}_{2} \mathrm{O}_{3}$ nanocatalysts calcined under different atmospheres.

\begin{tabular}{lccc}
\hline & \multicolumn{2}{c}{ Specific surface area $\left(\mathrm{m}^{2} / \mathrm{g}\right)$} \\
\hline Calcination atmosphere & Precursor & Fresh calcined (before test) & Used calcined (after test) \\
\hline Air & $\mathbf{1 5 7 . 3}$ & $\mathbf{2 1 2 . 2}$ & $\mathbf{1 9 6 . 8}$ \\
Nitrogen & 157.3 & 186.3 & 167.1 \\
\hline
\end{tabular}

Note. The bold values show the optimal condition. 


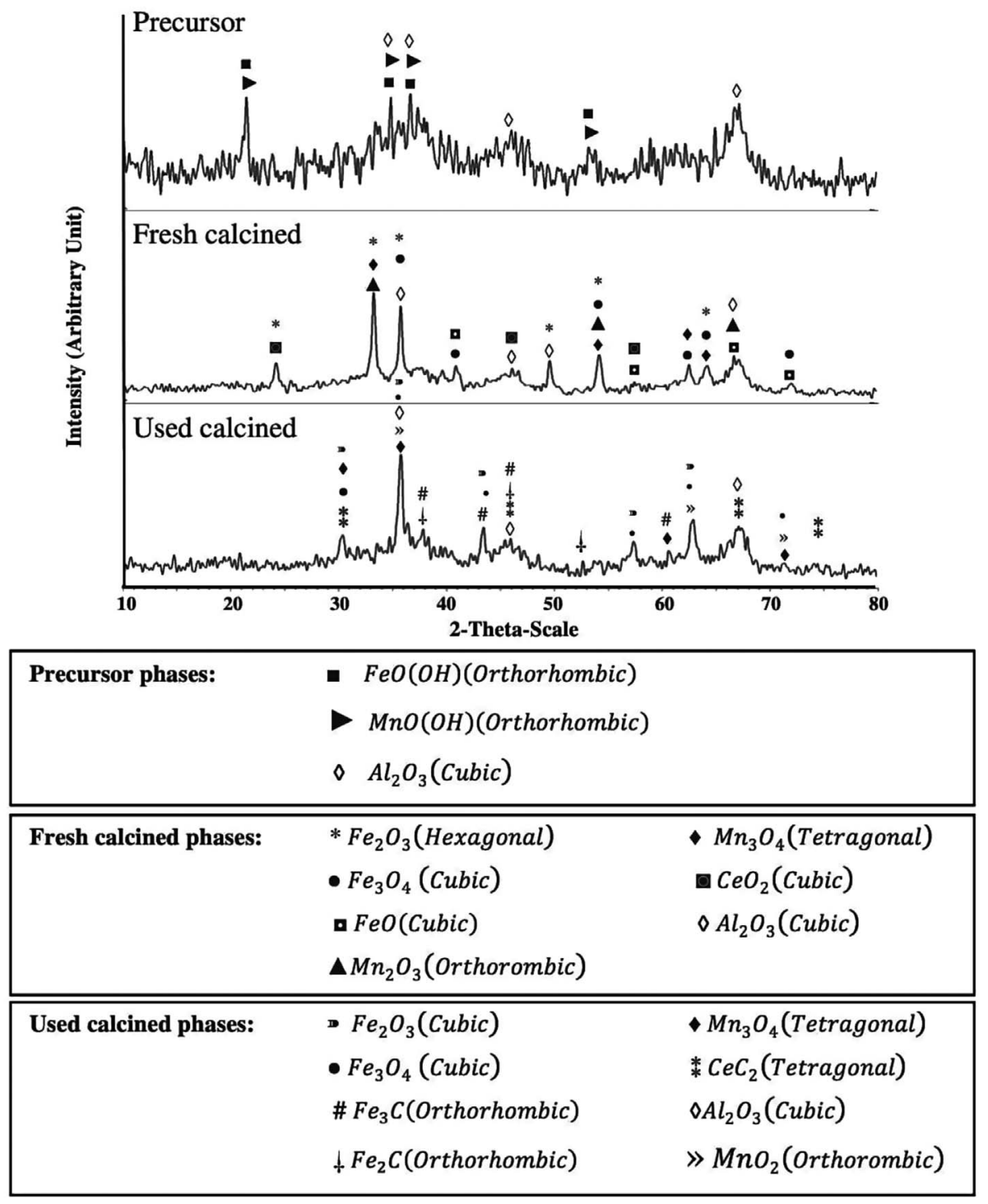

Fig. 5. The XRD patterns of optimal Fe-Mn-Ceternary nanocatalyst.

selectivity to light olefins so, this acceptable performance is more relevant to the set of phases, especially manganese oxides, which are not present in the sample calcined under nitrogen atmosphere. BET measurements of calcined catalysts under different atmospheres were performed and the related results are listed in Table 8.

The data in Tables 7 and 8 indicate that the catalyst calcined under air atmosphere has a higher specific surface area and consequently more catalytic activity.

\subsection{Characterization of the optimal Fe-Mn-Ce ternary nanocatalyst supported on $\gamma$-Al2O3}

\subsubsection{X-Ray diffraction}

As the 75 wt $\% \mathrm{Fe}-20 \mathrm{wt} \% \mathrm{Mn}-5 \mathrm{wt} \% \mathrm{Ce} / \mathrm{Al}_{2} \mathrm{O}_{3}$ nanocatalyst calcined at $500{ }^{\circ} \mathrm{C}$ for $7 \mathrm{~h}$ under air atmosphere was selected as the optimal system, so the optimum catalyst phase changes in different modes including precursor, fresh (before FTS) and used (after FTS) calcined were evaluated by XRD technique. Figure 5 shows the XRD pattern obtained from these samples.

As can be seen, the precursor of this catalyst comprises the hydroxide and oxide phases and the fresh calcined catalyst (before FTS) contains the oxide phases. The Fischer-Tropsch reaction on the catalyst surface results in the change of its phases and in the used calcined catalyst (after FTS) the carbide and oxide phases are observed that these phases are active in the Fischer-Tropsch synthesis [49].

\subsubsection{BET}

BET technique was conducted to investigate the specific surface area and the amount of catalyst porosity (pore volume and diameter). The BET results for optimal nanocatalyst are reported in Table 9. As can be seen, alumina support showed the most specific surface area 
Table 9. BET analysis of the optimal Fe-Mn-Ce ternary nanocatalyst.

\begin{tabular}{lccc}
\hline Catalyst & \multicolumn{3}{c}{ BET results } \\
\cline { 2 - 4 } & $\mathrm{SSA}\left(\mathrm{m}^{2} / \mathrm{g}\right)$ & $\mathrm{PV}\left(\mathrm{cm}^{3} / \mathrm{g}\right)$ & PS $(\mathrm{nm})$ \\
\hline Support & 292.4 & 0.131 & 2.309 \\
Precursor & 157.3 & 0.078 & 2.035 \\
Fresh Calcined (before FTS) & 212.2 & 0.104 & 2.262 \\
Used Calcined (after FTS) & 196.8 & 0.062 & 1.194 \\
\hline
\end{tabular}

SSA: Specific Surface Area; PV: Pore Volume; PS: Pore Size.
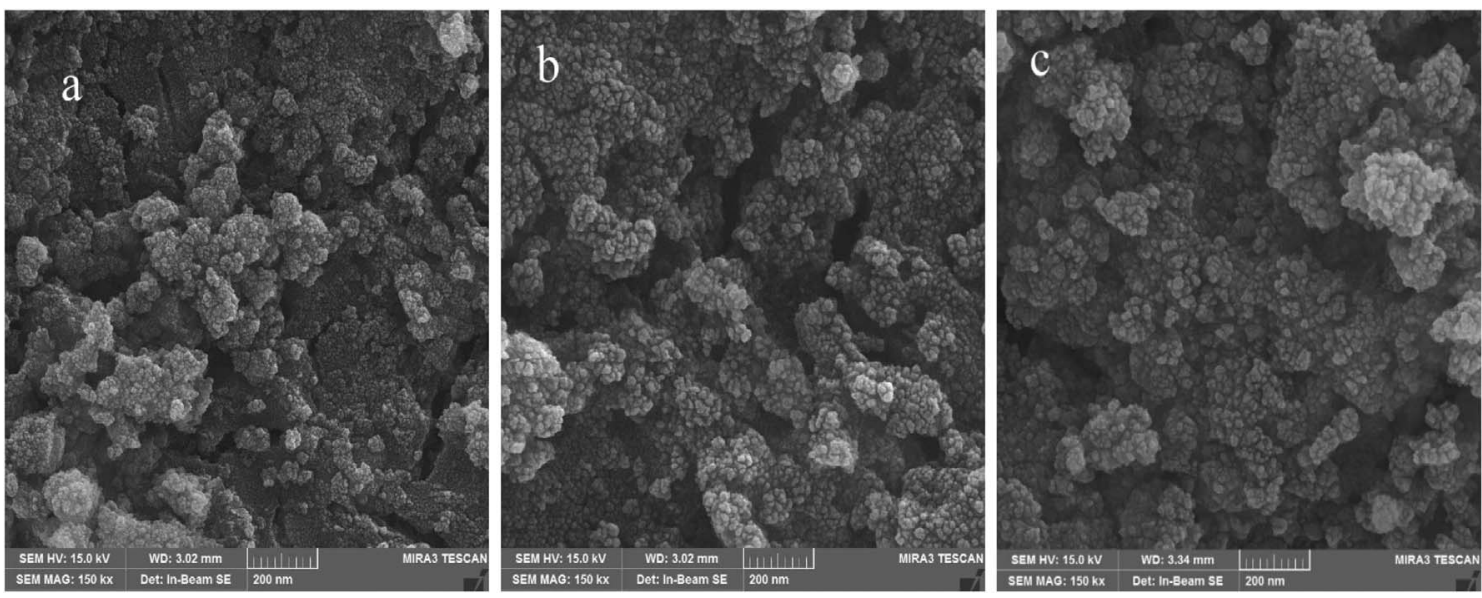

Fig. 6. The FE-SEM images of the optimal Fe-Mn-Ce ternary nanocatalyst: (a) precursor, (b) before FTS and (c) after FTS.

compared to other items. This is because metallic nitrates were used during the impregnation process and the precursor sample contains large nitrate and hydroxide phases that occupy the support surface, resulting in a much lower precursor specific surface area than the pure support. After calcination, the specific surface area of the sample is increased compared to the precursor due to the formation of oxide phases and the exit of nitrate and hydroxide phases. And in the sample after the reactor test compared to the sample before the reactor test due to the formation of coke and carbide phases, there is a decrease in the specific surface area. The porosity of this sample varies in different modes i.e. precursor, before and after the FTS. In other words, the volume and diameter of the cavities vary. However, changes in the specific surface area and porosity data have a direct relationship. Of course, these different porosity values also occur due to the influence of the calcination process and the FT reaction on the catalyst. In addition, the BET data are in excellent consistency with the XRD and EDAX data.

\subsubsection{FE-SEM, EDAX and MAP}

FE-SEM technique was carried out to study the morphology of optimal Fe-Mn-Ce ternary nanocatalyst samples. The FE-SEM images obtained are shown in Figure 6.

The Field Emission-SEM micrographs of precursor (Fig. 6a), fresh (Fig. 6b) and used calcined catalyst
(Fig. 6b) express that optimal catalyst samples have various surface morphologies. Examination of these images shows that the precursor (Fig. 7a) contains interconnected and dense particles, but during the calcination process, these particles become smaller and finer due to the formation of new phases and the escape of volatiles, also some groove-like structures are visible in the Figure 6b. After performing the reactor test, the catalyst morphology changes again and the groove structures are crumbled and filled (Fig. 6c). This change in the catalyst texture occurs due to the reaction on the surface and the formation of its carbide phases. This collapse of the catalyst texture is in agreement with the BET results, which show a decrease in the specific surface area of the sample tested in laboratory fixed bed tubular micro reactor.

The elemental compositions of optimal Fe-Mn-Ce ternary nanocatalyst samples attained from the EDAX data are presented in Table 10. Also, The EDAX spectra of the precursor and calcined catalysts are displayed in Fig. 7.

The EDAX spectrum of the precursor showed the presence of $\mathrm{Al}, \mathrm{O}, \mathrm{Fe}, \mathrm{Mn}$ and Ce (Tab. 10 and Fig. 7a). These identified elements are in consistency with the results of the catalyst precursor XRD (Fig. 5) which implies to hydroxide and oxide compounds of iron, manganese, cerium and aluminum. By the same way, the EDAX spectrum of the fresh calcined catalyst implies to oxide phases of iron, manganese, cerium and aluminum. In calcined catalyst 

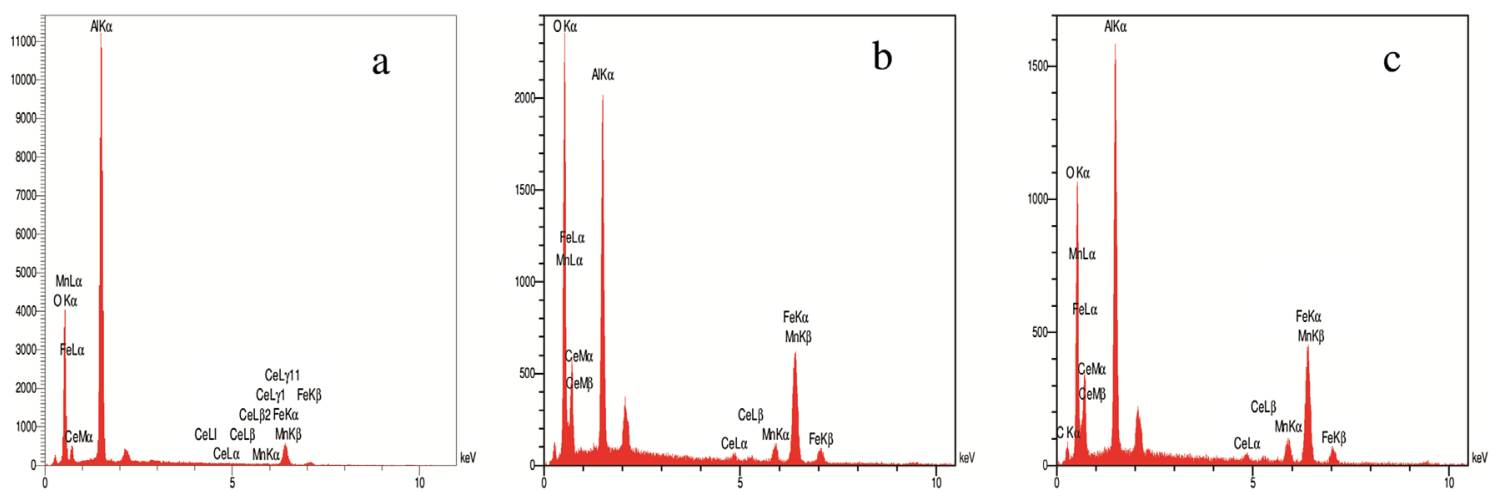

Fig. 7. EDAX spectrums of the optimal Fe-Mn-Ce ternary nanocatalyst: (a) precursor, (b) before FTS and (c) after FTS.

Table 10. EDAX data of the optimal $\mathrm{Fe}-\mathrm{Mn}-\mathrm{Ce}$ ternary nanocatalyst.

\begin{tabular}{llcc}
\hline Catalyst & Elements & Weight\% & Atomic\% \\
\hline Precursor & $\mathrm{O}$ & 46.14 & 62.51 \\
& $\mathrm{Al}$ & 40.01 & 32.15 \\
& $\mathrm{Mn}$ & 0.13 & 0.05 \\
& $\mathrm{Fe}$ & 13.55 & 05.26 \\
& $\mathrm{Ce}$ & 0.17 & 0.03 \\
Fresh Calcined catalyst (before the test) & $\mathrm{O}$ & 44.88 & 68.05 \\
& $\mathrm{Al}$ & $\mathrm{Mn}$ & 18.13 \\
& $\mathrm{Fe}$ & 3.37 & 1.49 \\
& $\mathrm{Ce}$ & 31.95 & 13.88 \\
Used Calcined catalyst (after the test) & $\mathrm{C}$ & 1.68 & 0.29 \\
& $\mathrm{O}$ & 11.86 & 22.20 \\
& $\mathrm{Al}$ & 37.73 & 53.02 \\
& $\mathrm{Mn}$ & 11.52 & 9.60 \\
& $\mathrm{Fe}$ & 4.99 & 02.04 \\
& $\mathrm{Ce}$ & 31.77 & 12.79 \\
\hline
\end{tabular}

after FTS the following elements involving $\mathrm{C}, \mathrm{O}, \mathrm{Al}, \mathrm{Fe}$, $\mathrm{Mn}$ and Ce have been detected (Tab. 10, Figs. 5 and 7c). These identified elements indicate that the sample after the reactor test contains oxide, metal, and carbide phases, as well as the reduction of oxygen content in the sample after the reactor test compared to the sample before the reactor test, indicating conversion of the oxide phases to the carbide phases. For investigation of the distribution of metals in calcined sample before reactor testing, metal mapping analysis was performed. Elemental mapping images of 75 wt $\% \quad \mathrm{Fe}-20$ wt\%Mn-5 wt\% $\mathrm{Ce} / \mathrm{Al}_{2} \mathrm{O}_{3}$ nanocatalyst calcined at $500{ }^{\circ} \mathrm{C}$ for $7 \mathrm{~h}$ under air are illustrated in Figure 8.

As can be seen in the MAP images, the distribution of the elements is homogeneous. In addition, the elemental distribution coincides with the EDAX data (Tab. 10, Fig. 7b), including weight and atomic percentage of the elements in the sample before the reactor testing.

\subsection{4 $H_{2^{-}}$TPR}

The reducibility analysis of optimal calcined catalyst was performed by $\mathrm{H}_{2}$-TPR and related curve is shown in Figure 9.

As can be seen, the TPR curve of the optimal calcined $\mathrm{Fe}-\mathrm{Mn}-\mathrm{Ce}$ ternary nanocatalyst illustrated four distinguished reduction peaks at $320,440,620$ and $850^{\circ} \mathrm{C}$ respectively. The sharp peak at approximately $320{ }^{\circ} \mathrm{C}$ corresponds to the reduction of $\mathrm{Fe}_{2} \mathrm{O}_{3}$ to $\mathrm{Fe}_{3} \mathrm{O}_{4}$. The sharp peak at $440{ }^{\circ} \mathrm{C}$ is pertinent to the reduction of $\mathrm{Fe}_{3} \mathrm{O}_{4}$ to $\mathrm{FeO}$ and also to the reduction of $\mathrm{CeO}_{2}$ to $\mathrm{Ce}_{2} \mathrm{O}_{3}\left(\mathrm{Ce}^{+4}\right.$ to $\mathrm{Ce}^{+3}$ ). The broad peak in the temperature range of 580 $640^{\circ} \mathrm{C}$ is ascribed to the reduction of the third stage of iron oxide and its conversion to metallic form $\left(\mathrm{FeO}\right.$ to $\left.\mathrm{Fe}^{0}\right)$ and $\mathrm{Mn}_{2} \mathrm{O}_{3}$ to $\mathrm{Mn}_{3} \mathrm{O}_{4}$. The final broad peak about $850{ }^{\circ} \mathrm{C}$ can be related to reduction of $\mathrm{Ce}_{2} \mathrm{O}_{3}$ to $\mathrm{CeO}$ and Manganese oxide reduction from $\mathrm{Mn}_{3} \mathrm{O}_{4}$ to $\mathrm{MnO}$. In accordance with 

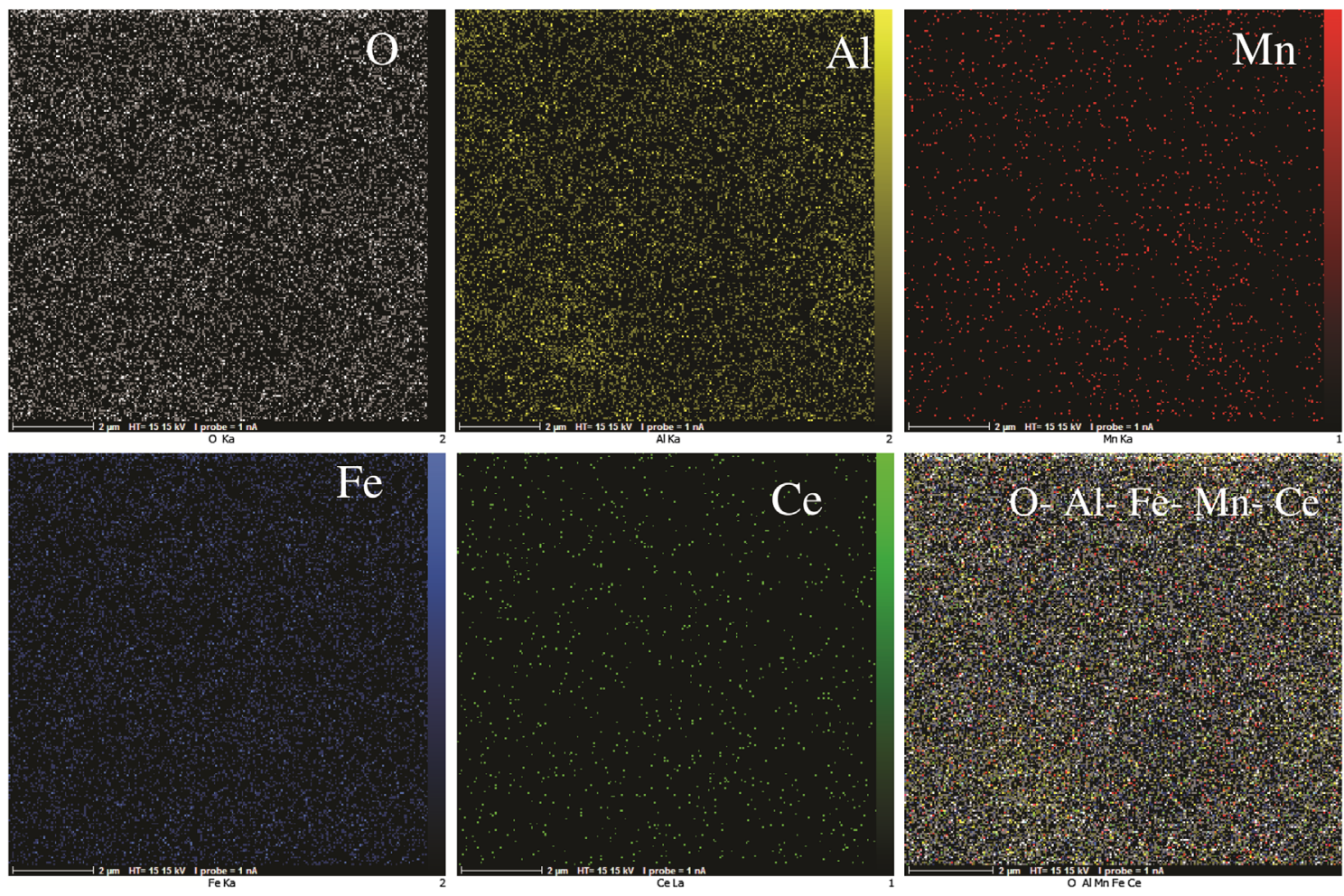

Fig. 8. Elemental mapping images of fresh calcined $\mathrm{Fe}-\mathrm{Mn}-\mathrm{Ce} / \mathrm{Al}_{2} \mathrm{O}_{3}$ nanocatalyst (before FTS).

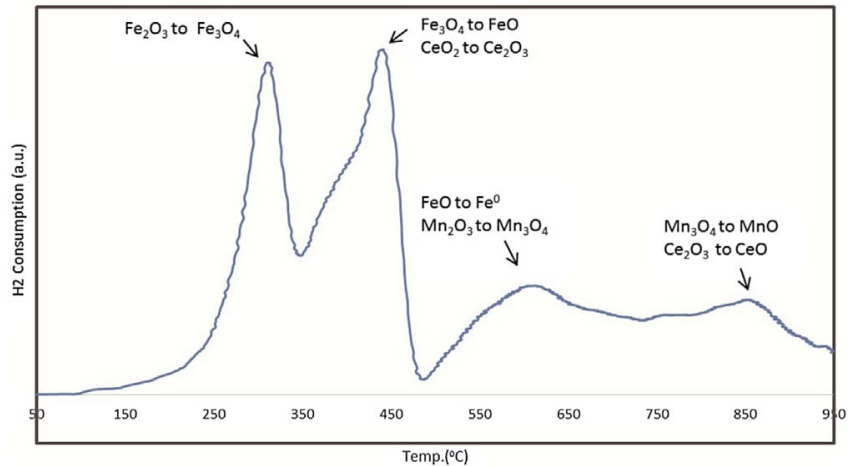

Fig. 9. $\mathrm{H}_{2}$-TPR curve of calcined $\mathrm{Fe}-\mathrm{Mn}-\mathrm{Ce}$ ternary nanocatalyst.

the XRD (Fig. 5) and TPR curves (Fig. 9), we can find that the $\mathrm{Fe}_{2} \mathrm{O}_{3}$ phases in calcined sample changed to $\mathrm{Fe}$ and $\mathrm{FeO}$ after $\mathrm{H}_{2}$ reduction. After the calcined nanocatalyst was placed into the reactor chamber and during reduction process and FTS, a part of the metallic phases for example Fe is converted to $\mathrm{Fe}_{3} \mathrm{C}$ and $\mathrm{Fe}_{2} \mathrm{C}$ carbides. The iron carbides formed on the nanocatalyst surface raise the FT performance and selectivity to light olefins [24, 50].

\subsubsection{TG/DSC}

TG/DSC analysis over optimal $\mathrm{Fe}-\mathrm{Mn}-\mathrm{Ce}$ precursor was performed to evaluate the thermal behavior of the catalyst.

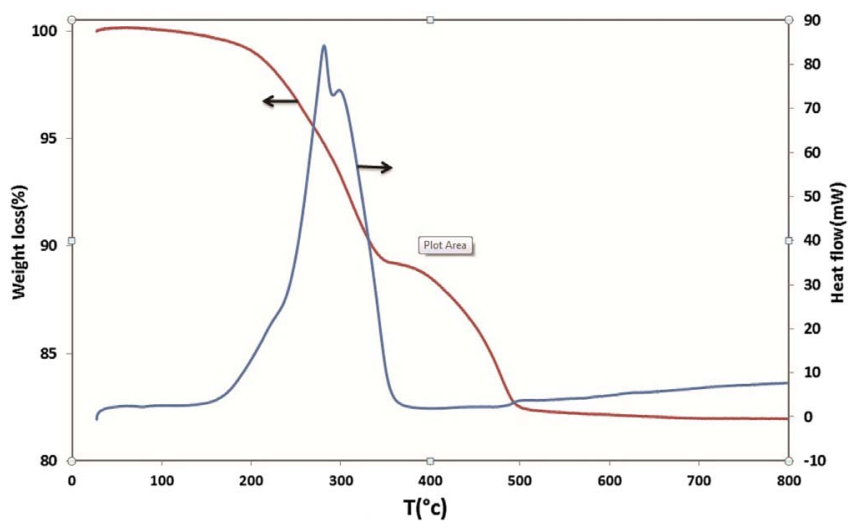

Fig. 10. TG/ DSC curves for optimal Fe-Mn-Ce precursor.

Fig. 10 illustrates that, as the temperature increased from ambient temperature to $490{ }^{\circ} \mathrm{C}$, the precursor suffered an $18 \%$ weight loss.

For this precursor, there are two main stages of weight loss. The first stage occurs from $200{ }^{\circ} \mathrm{C}$ to $350{ }^{\circ} \mathrm{C}$, and the next stage occurs from $350{ }^{\circ} \mathrm{C}$ to $490{ }^{\circ} \mathrm{C}$ which are related to the loss of crystallization water and the decomposition of the hydroxide and nitrate phases present in the sample. At temperatures above $490{ }^{\circ} \mathrm{C}$, no weight loss was observed in this sample indicating the production of stable oxide phases. The DSC spectrum also shows two endothermic peaks, which is consistent with the TG data. 


\section{Conclusion}

The catalyst composition and calcination parameters play key roles in FTS activity and its products selectivity especially the light olefins. For the first time, the $\mathrm{Fe}-\mathrm{Mn}-\mathrm{Ce}$ ternary nanocatalysts supported on alumina granules were synthesized by incipient wetness impregnation under vacuum procedure in various weight ratios of metals. The most appropriate weight percentage of all of the catalysts was belonged to nanocatalyst with $75 \mathrm{wt} \% \mathrm{Fe}-20 \mathrm{wt} \% \mathrm{Mn}-5$ wt\% $\mathrm{Ce} / \mathrm{Al}_{2} \mathrm{O}_{3}$. The reason for that is the higher olefins $\left(\mathrm{C}_{2}^{=}-\mathrm{C}_{4}^{=}\right)$production and maximize the ratio of olefin to total sum of methane and paraffin $(\mathrm{O} /(\mathrm{M}+\mathrm{P}))$. Then the influence of calcination parameters on the nanocatalysts performance and structure was evaluated. It became clear that, at calcination temperatures above $500{ }^{\circ} \mathrm{C}$ and calcination times above $7 \mathrm{~h}$ the catalyst performance decreased. This decrease in catalyst performance is due to the decrease in specific surface area and catalyst surface active centers. Calcination in nitrogen atmosphere reduces production of desirable products, namely light olefins and consequently reduces the nanocatalysts activity. The nanocatalysts are characterized by different techniques such as XRD, $\mathrm{N}_{2}$ adsorption-desorption, FE-SEM, EDAX, MAP, TG/ DSC, and $\mathrm{H}_{2}-\mathrm{TPR}$. The obtained results corroborate that the structural, morphological and physic-chemical properties of the nanocatalyst have been impressed with metal species and calcination parameters. The optimum nanocatalyst has a good performance due to the homogeneous distribution on the alumina support and the existence of iron oxides and carbides as active phases of the FT process. Finally, the $75 \% \mathrm{Fe}-20 \% \mathrm{Mn}-5 \% \mathrm{Ce} / \mathrm{Al}_{2} \mathrm{O}_{3}$ nanocatalyst calcined at $500{ }^{\circ} \mathrm{C}$ for $7 \mathrm{~h}$ under static air was selected as the optimal nanocatalyst for Fischer-Tropsch synthesis in present research.

Acknowledgments. Special thanks to the Ministry of Science, Research and Technology of the Islamic Republic of Iran and University of Sistan and Baluchestan for the financial and instrumental supports.

\section{References}

1 Abbasi M., Mirzaei A.A., Atashi H. (2019) Hydrothermal synthesis of Fe-Ni-Ce nano-structure catalyst for FischerTropsch synthesis: Characterization and catalytic performance, J. Alloys Compd. 799, 546-555. https://doi.org/ 10.1016/j.jallcom.2019.05.314.

2 Akbari M., Mirzaei A.A., Atashi H., Arsalanfar M. (2018) Effect of microemulsion parameters on product selectivity of $\mathrm{MgO}$-supported iron-cobalt-manganese-potassium nanocatalyst for Fischer-Tropsch synthesis using response surface methodology, J. Taiwan Inst. Chem. Eng. 91, 396-404. https://doi.org/10.1016/j.jtice.2018.06.004.

3 Einbeigi A., Atashi H., Mirzaei A.A., Zohdi-Fasaei H., Golestan S. (2019) Development of new comprehensive kinetic models for Fischer-Tropsch synthesis process over $\mathrm{Fe}-\mathrm{Co} /$ $\gamma-\mathrm{Al}_{2} \mathrm{O}_{3}$ nanocatalyst in a fixed-bed reactor, J. Taiwan Inst. Chem. Eng. 103, 57-66. https://doi.org/10.1016/j.jtice. 2019.07.004.
4 Torres Galvis H.M., de Jong K.P. (2013) Catalysts for production of lower olefins from synthesis gas: a review, $A C S$ Catal. 3, 2130-2149. https://doi.org/10.1021/cs4003436.

5 Mansouri M., Atashi H., Tabrizi F.F., Mirzaei A.A., Mansouri G. (2013) Kinetics studies of nano-structured cobalt-manganese oxide catalysts in Fischer-Tropsch synthesis, J. Ind. Eng. Chem. 19, 1177-1183. https://doi.org/ 10.1016/j.jiec.2012.12.015.

6 Dry M.E. (1996) Practical and theoretical aspects of the catalytic Fischer-Tropsch process, Appl. Catal. A: Gen. 138, 319-344. https://doi.org/10.1016/0926-860X(95)00306-1.

7 Dry M.E. (2004) Present and future applications of the Fischer-Tropsch process, Appl. Catal. A: Gen. 276, 1-3. https://doi.org/10.1016/j.apcata.2004.08.014.

8 Steynberg A.P. (2004) Chapter 1 - Introduction to FischerTropsch Technology, in Studies in Surface Science and Catalysis, Vol. 152, A. Steynberg, M. Dry (eds), Elsevier, Amsterdam, pp. 1-63. https://doi.org/10.1016/S0167-2991 (04)80458-0.

9 Geerlings J.J.C., Wilson J.H., Kramer G.J., Kuipers H.P.C.E., Hoek A., Huisman H.M. (1999) Fischer-Tropsch technologyfrom active site to commercial process, Appl. Catal. A Gen. 186, 27-40. https://doi.org/10.1016/S0926-860X(99)00162-3.

10 Abbasi S., Abbasi M., Tabkhi F., Akhlaghi B. (2020) Syngas production plus reducing carbon dioxide emission using dry reforming of methane: utilizing low-cost Ni-based catalysts, Oil Gas Sci. Technol. - Rev. IFP Energies nouvelles 75, 22. https://doi.org/10.2516/ogst/2020016.

11 Van Der Laan G.P., Beenackers A. (1999) Kinetics and selectivity of the Fischer-Tropsch synthesis: a literature review, Catal. Rev. 41, 255-318. https://doi.org/10.1081/ CR-100101170.

12 Wu X., Qian W., Ma H., Zhang H., Liu D., Sun Q., Ying W. (2019) Li-decorated Fe-Mnnanocatalyst for high-temperature Fischer-Tropsch synthesis of light olefins, Fuel 257, 116101. https://doi.org/10.1016/j.fuel.2019.116101.

13 Jiao F., Li J., Pan X., Xiao J., Li H., Ma H., Wei M., Pan Y., Zhou Z., Li M., Miao S., Li J., Zhu Y., Xiao D., He T., Yang J., Qi F., Fu Q., Bao X. (2016) Selective conversion of syngas to light olefins, Science 351, 1065-1068. https://doi. org/10.1126/science.aaf1835.

14 Arsalanfar M., Mirzaei A., Atashi H., Bozorgzadeh H., Vahid S., Zare A. (2012) An investigation of the kinetics and mechanism of Fischer-Tropsch synthesis on $\mathrm{Fe}-\mathrm{Co}-\mathrm{Mn}$ supported catalyst, Fuel Process. Technol. 96, 150-159. https://doi.org/10.1016/j.fuproc.2011.12.018.

15 Liu Y., Teng B.-T., Guo X.-H., Li Y., Chang J., Tian L., Hao X., Wang Y., Xiang H.-W., Xu Y.-Y., Li Y.-W. (2007) Effect of reaction conditions on the catalytic performance of Fe-Mn catalyst for Fischer-Tropsch synthesis, Mol. Catal. 272, 182-190. https://doi.org/10.1016/j.molcata.2007.03.046.

16 Li X., Luo M., Asami K. (2004) Direct synthesis of middle iso-paraffins from synthesis gas on hybrid catalysts, Catal. Today 89, 439-446. https://doi.org/10.1016/j.cattod.2004. 03.054 .

17 Qian W., Zhang H., Ying W., Fang D. (2013) The comprehensive kinetics of Fischer-Tropsch synthesis over a $\mathrm{Co} / \mathrm{AC}$ catalyst on the basis of CO insertion mechanism, Chem. Eng. J. 228, 526-534. https://doi.org/10.1016/j.cej.2013.05.039.

18 Luo M., Hamdeh H., Davis B.H. (2009) Fischer-Tropsch Synthesis: Catalyst activation of low alpha iron catalyst, Catal. Today 140, 127-134. https://doi.org/10.1016/ j.cattod.2008.10.004. 
19 Cano L.A., Cagnoli M.V., Bengoa J.F., Alvarez A.M., Marchetti S.G. (2011) Effect of the activation atmosphere on the activity of Fe catalysts supported on SBA-15 in the Fischer-Tropsch Synthesis, J. Catal. 278, 310-320. https://doi.org/10.1016/j.jcat.2010.12.017.

20 Lox E.S., Marin G.B., De Grave E., Bussière P. (1988) Characterization of a promoted precipitated iron catalyst for Fischer-Tropsch synthesis, Appl. Catal. 40, 197-218. https://doi.org/10.1016/S0166-9834(00)80438-8.

21 Dry M.E. (1981) The Fischer-Tropsch synthesis, in Catalysis Science and Technology, Vol. 1, J.R. Anderson, M. Boudart (eds.), Springer-Verlag, Berlin, pp. 159-255.

22 King D., Cusumano J., Garten R.L. (1981) A technological perspective for catalytic processes based on synthesis gas, Catal. Rev. 23, 233-263. https://doi.org/10.1080/ 03602458108068077.

23 Fernandes F.A.N., Sousa E.M.M. (2006) Fischer-Tropsch synthesis product grade optimization in a fluidized bed reactor, AIChE J. 52, 2844-2850. https://doi.org/10.1002/ aic. 10887 .

24 Feyzi M., Khodaei M.M., Shahmoradi J. (2015) Preparation and characterization of promoted Fe-Mn/ZSM-5 nano catalysts for CO hydrogenation, Int. J. Hydrog. Energy 40, 1481614825. https://doi.org/10.1016/j.ijhydene.2015.09.020.

25 Barrault J., Renard C. (1985) Selective hydrocondensation of carbon monoxide into light olefins with iron-manganese catalysts, Appl. Catal. 14, 133-143. https://doi.org/ 10.1016/S0166-9834(00)84350-X.

26 Yang Y., Xiang H.-W., Xu Y.-Y., Bai L., Li Y.W. (2004) Effect of potassium promoter on precipitated iron-manganese catalyst for Fischer-Tropsch synthesis, Appl. Catal A: Gen. 266, 181-194. https://doi.org/10.1016/j.apcata.2004.02.018.

27 Yang Y., Xiang H.W., Tian L., Wang H., Zhang C.H., Tao Z.-C., Xu Y.Y., Bing Z., Li Y.W. (2005) Structure and Fischer-Tropsch performance of iron-manganese catalyst incorporated with $\mathrm{SiO}_{2}$, Appl. Catal A: Gen. 284, 105-122. https://doi.org/10.1016/j.apcata.2005.01.025.

28 Zhang X., Liu Y., Liu G., Kurokawa Y., Fan R., Tao K., Meng F., Jin Q., Kawabata T., Matsuda K., Ikeno S., Tsubaki N. (2010) One-Step Preparation of Bimodal $\mathrm{Fe}-\mathrm{Mn}-\mathrm{K} / \mathrm{SiO}_{2}$ Catalyst and its Catalytic Performance of Slurry Phase Fischer-Tropsch Synthesis, Catal. Lett. 139, 7-16. https://doi.org/10.1007/s10562-010-0381-5.

29 Yang Y., Xiang H., Zhang R., Zhong B., Li Y.W. (2005) A highly active and stable Fe-Mn catalyst for slurry FischerTropsch synthesis, Catal. Today 106, 170-175. https://doi. org/10.1016/j.cattod.2005.07.127.

30 Herranz T., Rojas S., Pérez-Alonso F., Ojeda M., Terreros P., Fierro J.L.G. (2006) Hydrogenation of carbon oxides over promoted Fe-Mn catalysts prepared by the microemulsion methodology, Appl. Catal A: Gen. 311, 66-75. https://doi. org/10.1016/j.apcata.2006.06.007.

31 Zhang C.-H., Yang Y., Teng B.-T., Li T.-Z., Zheng H.-Y., et al. (2006) Study of an iron-manganese Fischer-Tropsch synthesis catalyst promoted with copper, J. Catal. 237, 405-415. https://doi.org/10.1016/j.jcat.2005.11.004.

32 Maiti G.C., Malessa R., Baerns M. (1983) Iron/manganese oxide catalysts for fischer-tropsch synthesis: Part I: structural and textural changes by calcination, reduction and synthesis, Appl. Catal. 5, 151-170. https://doi.org/10.1016/ 0166-9834(83)80129-8.

33 Taherzadeh Lari T., Mirzaei A.A., Atashi H. (2016) Influence of fabrication temperature and time on light olefin selectivity of iron-cobalt-cerium mixed oxide nanocatalyst for CO hydrogenation, Ind. Eng. Chem. Res. 55, 1299113007. https://doi.org/10.1021/acs.iecr.6b03171.

34 Barrault J., Probst S., Alouche A., Percheron-Guecan A., Paul-Boncour V., Primet M. (1991) Characterization and catalytic properties of nickel oxioe supported on rare earth oxides. Description of the metal - support interaction, Stud. Surf. Sci. Catal. 61, 357-365. https://doi.org/10.1016/ S0167-2991(08)60101-9.

35 Barrault J., Guilleminot A., Achard J., Paul-Boncour V., Percheron-Guegan A. (1986) Hydrogenation of carbon monoxide on carbon-supported cobalt rare earth catalysts, Appl. Catal. 21, 307-312. https://doi.org/10.1016/S01669834(00)81363-9.

36 Cheng K., Ordomsky V.V., Virginie M., Legras B., Chernavskii P.A., et al. (2014) Support effects in high temperature Fischer-Tropsch synthesis on iron catalysts, Appl. Catal A: Gen. 488, 66-77. https://doi.org/10.1016/j. apcata.2014.09.033.

37 Bao J., Yang G., Okada C., Yoneyama Y., Tsubaki N. (2011) H-type zeolite coated iron-based multiple-functional catalyst for direct synthesis of middle isoparaffins from syngas, Appl. Catal A: Gen. 394, 195-200. https://doi.org/10.1016/j. apcata.2010.12.041.

38 Suo H., Wang S., Zhang C., Xu J., Wu B., Yang Y. (2012) Chemical and structural effects of silica in iron-based Fischer-Tropsch synthesis catalysts, J. Catal. 286, 111123. https://doi.org/10.1016/j.jcat.2011.10.024.

39 De Jong K.P., Geus J.W. (2000) Carbon nanofibers: catalytic synthesis and applications, Catal. Rev. 42, 481-510. https://doi.org/10.1081/CR-100101954.

40 Rankin J.L., Bartholomew C.H. (1986) Effects of potassium and calcination pretreatment on the adsorption and chem$\mathrm{ical} /$ physical properties of $\mathrm{FeSiO}_{2}$, J. Catal. 100, 533-540. https://doi.org/10.1016/0021-9517(86)90126-0.

41 Rankin J.L., Bartholomew C.H. (1986) Effects of calcination on the CO hydrogenation activity/selectivity properties of potassium-promoted iron/silica, J. Catal. 100, 526-532. https://doi.org/10.1016/0021-9517(86)90125-9.

42 Feyzi M., Irandoust M., Mirzaei A.A. (2011) Effects of promoters and calcination conditions on the catalytic performance of iron-manganese catalysts for FischerTropsch synthesis, Fuel Process Technol. 92, 1136-1143. https://doi.org/10.1016/j.fuproc.2011.01.010.

43 Torshizi H.O., Vahid S., Mirzaei A.A. (2014) Kinetics modeling of Fischer-Tropsch synthesis on the unsupported Fe-Co-Ni (ternary) catalyst prepared using co-precipitation procedure, J. Nat. Gas Sci. Eng. 17, 110-118. https://doi. org/10.1016/j.fuel.2014.09.093.

44 Mirzaei A.A., Galavy M., Beigbabaei A., Eslamimanesh V. (2007) Preparation and operating conditions for cobalt cerium oxide catalysts used in the conversion of synthesis gas into light olefins, J. Iran. Chem. Soc. 4, 347-363. https://doi.org/10.1007/BF03245986.

45 Mirzaei A.A., Galavy M., Eslamimanesh V. (2008) SEM and BET Methods for investigating the structure and morphology of $\mathrm{Co}-\mathrm{Ce}$ catalysts for production of light olefins, Aust. J. Chem. 61, 144-152. https://doi.org/ 10.1071/CH07130.

46 Mirzaei A.A., Shahriari S., Arsalanfar M. (2011) Effect of preparation conditions on the catalytic performance of $\mathrm{Co} /$ Ni catalysts for CO hydrogenation, J. Nat. Gas Sci. Eng. 3, 537-546. https://doi.org/10.1016/j.jngse.2011.06.003. 
47 Arsalanfar M., Mirzaei A.A., Bozorgzadeh H.R., Samimi A., Ghobadi R. (2014) Effect of support and promoter on the catalytic performance and structural properties of the $\mathrm{Fe}-\mathrm{Co}-\mathrm{Mn}$ catalysts for Fischer-Tropsch synthesis, J. Ind. Eng. Chem. 20, 1313-1323. https://doi.org/10.1016/j. jiec.2013.07.011.

48 Mirzaei A.A., Arsalanfar M., Bozorgzadeh H.R., Samimi A. R. (2014) A review of Fischer-Tropsch synthesis on the cobalt based catalysts, Phys. Chem. Res. 2, 179-201. https://doi.org/10.22036/pcr.2014.5786.
49 Shroff M.D., Kalakkad D.S., Coulter K.E., Kohler S.D., Harrington M.S., et al. (1995) Activation of precipitated iron Fischer-Tropsch synthesis catalysts, J. Catal. 156, 185-207. https://doi.org/10.1006/jcat.1995.1247.

50 Golestan S., Mirzaei A.A., Atashi H. (2017) Fischer-Tropsch synthesis over an iron-cobalt-manganese (ternary) nanocatalyst prepared by hydrothermal procedure: Effects of nanocatalyst composition and operational conditions, Int. J. Hydrog. Energy 42, 9816-9830. https://doi.org/10.1016/j. ijhydene.2017.01.162. 